\title{
Diagnostic accuracy of five different techniques for detection of approximal caries
}

\author{
Defne Yalçın Yeler, ${ }^{1 *}$ Melike Koraltan ${ }^{2}$ \\ ${ }^{1}$ Department of Oral and Maxillofacial Radiology, Faculty of \\ Dentistry, Cumhuriyet University, ${ }^{2}$ Oral and Dental Health \\ Hospital, Sivas, Turkey
}

\begin{abstract}
OвJестіVE: The aim of this study was to compare the accuracy of five different radiographic methods for the detection of approximal caries on posterior teeth.

Materials and Method: Seventy-two extracted posterior teeth with and without caries were studied. Intraoral bitewing radiographs were taken with film and a storage phosphor-plate system. Extraoral panoramic images were obtained by using the bitewing, orthogonal and standard programs of a digital panoramic radiography device. Images were evaluated by two observers. Intra- and interobserver weighted-kappa coefficients were calculated. Scores obtained from the five techniques were compared against the histological gold standard using receiver operating characteristics (ROC) curve analysis. Az values for each image type were compared using z-test and the level of statistical significance was set at 0.05 . Sensitivity, specificity and false-positive rates were calculated for each method.
\end{abstract}

RESULTS: Intra- and inter-observer agreement $\kappa$ values were between $0.59-0.88$ and $0.54-0.87$, respectively. The $A z$ value was greatest with conventional bitewing $(0.760)$ and phosphor plate bitewing $(0.756)$ and lowest with standard panoramic image program (0.639). The standard panoramic image program was significantly inferior to the other diagnostic methods $(p<0.05)$. Sensitivity and specificity values were $\mathbf{0 . 6 4}$ and $\mathbf{0 . 8 5}$ for conventional bitewing, 0.64 and 0.87 for phosphor plate bitewing, 0.40 and 0.87 for standard program, 0.56 and 0.85 for orthogonal program, and 0.59 and 0.90 for extraoral bitewing program, respectively.

Conclusion: In this study, conventional and phosphor plate bitewing images were found to confer similar diagnostic accuracy. Orthogonal and extraoral bitewing programs on panoramic devices were effective for

Received: February 24, 2017; Accepted: September 12, 2017

${ }^{*}$ Corresponding author: Dr. Defne Yalcın Yeler, Department of Oral and

Maxillofacial Radiography, Faculty of Dentistry, Cumhuriyet University, Sivas,

Turkey;

E-mail: dyeler@gmail.com reducing superimpositions. The diagnostic sensitivity of the studied methods for approximal caries was found to be low at the level of enamel.

KEYWORDS: Bitewing radiography; dental caries; panoramic radiography

Citatıon: Yalçın Yeler D, Koraltan M. Diagnostic accuracy of five different techniques for detection of approximal caries. Acta Odontol Turc 2018;35(1):9-16

Editor: Neşe Akal, Gazi University, Ankara, Turkey

CopyrıGHT: (C) 2018 Yalçın Yeler and Koraltan. This work is licensed under a Creative Commons Attribution License. Unrestricted use, distribution and reproduction in any medium is permitted provided the original author and source are credited.

\section{INTRODUCTION}

Timely and accurate diagnosis of dental caries is crucial for treatment planning and determination of an appropriate restorative technique. Primarily, early detection of non-cavitated enamel lesions is a matter of high significance, because progression of caries can be halted at this stage and dental tissue can also be preserved with minimally invasive approaches without the need for restorative treatment. ${ }^{1,2}$ On the other hand, due to challenges in clinical detection of approximal caries prior to cavitation, the ability to make a distinction between the presence or absence of a caries lesion (i.e. sensitivity and specificity) becomes important when imaging devices and methods are used for caries detection. Working with devices and modalities with a high sensitivity and specificity for approximal caries enables diagnosis of an actual caries promptly and accurately, and avoids any unnecessary cavitation surgery in a non-caries tooth. ${ }^{3}$ However, several studies reported that modalities and devices used for caries detection do not adequately identify caries lesions particularly when they are located at the enamel level. ${ }^{4}$

It was recommended that visual and clinical examinations should be combined with bitewing radiography in order to increase the detection rate of approximal caries. ${ }^{5,6}$ Currently, intraoral bitewing radiographs can be obtained by either film or digital sensors. Digital systems offer reduced patient exposure 
to radiation, time savings, image enhancement and ease of image storage, retrieval and transmission. On the other hand, they are associated with some disadvantages. Particularly, it is important to take necessary preventive actions to minimize the risk of cross-infection when using digital systems. Other drawbacks include high initial costs, artifacts that arise from scratching or damage to phosphor plates or laser scanner, and the concern for potential medico-legal issues. With current widespread use of advanced digital methods, an overall reduction in associated costs would be seen in the future and original software programs are developed by companies to avoid legal problems. ${ }^{7}$ However, traditional methods have not been yet fully replaced with digital methods. Film still remains the most convenient method of choice for bitewing examinations. ${ }^{8}$ Phosphor plate digital system is another major imaging modality commonly used to obtain intraoral digital images. In this system, a latent image is created and stored on the phosphor plate which is used as a sensor; then, the image is visualized by a laser scanner. ${ }^{9}$

There are also numerous digital panoramic systems used in clinical practice. Although these systems are not the method of choice for diagnosis of approximal caries and periapical lesions, they have become increasingly popular due to improved image quality, convenience, reduced radiation doses and a wider field of view. ${ }^{10}$ In addition, certain patient-related factors (trismus, gagging reflex, low cost) make panoramic radiography advantageous. ${ }^{11}$

Panoramic radiography is a simple method for obtaining images by the synchronous rotation of the $x$-ray source and image receptor around the stationary patient but there is a magnifying factor associated with the image formation because of the distances between the radiation source, patient and image receptor. Additionally, projection geometry causes image distortion and superimpositions in the premolar region. Newer orthogonal and extraoral bitewing projections have been developed to achieve greater success in the diagnosis of approximal caries by reducing superimpositions in the premolar region. ${ }^{12,13}$

Few studies are available in literature that compared intraoral and extraoral modalities for detection of approximal caries lesions using different devices. ${ }^{14,15}$ The present study aimed to compare the diagnostic ability of five different radiographic imaging methods (conventional and digital bitewing radiography, standard panoramic, orthogonal panoramic and extraoral bitewing radiography) in detecting approximal caries in posterior teeth in vitro.

\section{Materials And Method}

\section{Teeth and jaw models}

Through a statistical power analysis (alpha $=0.05$, $\beta=0.20$, and $1-\beta=0.80$ ), it was estimated that 70 teeth should be included in the study and the power of the test was 0.8956 . In this study, 72 human premolar and permanent molar teeth with or without approximal caries that had been extracted for caries, periodontal disease or orthodontic reasons were used. Teeth that had approximal caries without occlusal caries and sound approximal surface on visual examination were included in this study. The study protocol was approved by the Ethics Committee for Clinical Research of Cumhuriyet University (2014-11/16). First, the teeth were cleaned of calculus and disinfected in $10 \%$ formaldehyde solution and then stored in distilled water. Subsequently, all teeth were split into crown and root sections using fissure burs. The crowns were embedded in wax blocks without considering their caries presence/level, randomly, in groups of four (two maxillary/two mandibular molars and two maxillary/ two mandibular premolars, depending on the region in which they would be placed) with the proximal surfaces in contact, and all blocks and teeth were numbered. A total of 18 (9 maxillary and 9 mandibular) groups were obtained.

Standard acrylic jaw models were obtained and one premolar-molar region from each jaw was scraped. Then, each block of crowns was placed in the scraped location of maxillary or mandibular acrylic jaw models as appropriate and occluded and fixed by wax. Each jaw model had lead balls in non-scraped molar and incisor teeth areas for standardization. Mesial and distal aspects of the 4 teeth in each group were assessed for caries using 5 different radiographic methods. A 12-mm thick acrylic phantom was placed in front of the teeth to simulate soft tissue.

\section{Conventional film-based radiography}

A bitewing technique using an E/F speed film (Eastman Kodak Company, Rochester, NY, USA) and standardized bitewing projection with film holder were used. Satelec X-mind AC intraoral X-ray unit (Satelec Acteon Group, Merignac, France) was operated at 70 $\mathrm{kV}, 8 \mathrm{~mA}, 0.5 \mathrm{sec}$ with a focus-receptor distance of $30 \mathrm{~cm}$. Films were automatically processed (Velopex Extra-X, Medivance Instruments Limited, London, UK) on the same day using fresh chemicals. Figure $1 \mathrm{~A}$ shows the conventional radiographic image of an approximal surface.

\section{Storage phosphor plate system}

Standardized digital images of the teeth were obtained (with film holder) using the same intraoral X-ray unit. Exposure parameters were $70 \mathrm{kV}, 8 \mathrm{~mA}, 0.125 \mathrm{sec}$ with a focus-receptor distance of $30 \mathrm{~cm}$. The storage phosphor plate (Instrumentarium Express, Instrumentarium Dental, Tuusula, Finland) was immediately scanned after exposure by an Instrumentarium Express scanner (with the proprietary software Cliniview ${ }^{\mathrm{TM}}$ ). Scanner resolution was set at $14.3 \mathrm{lp} / \mathrm{mm}, 14-b i t$ contrast. Figure $1 \mathrm{~B}$ shows the storage phosphor plate image of the approximal surface of the same tooth. 


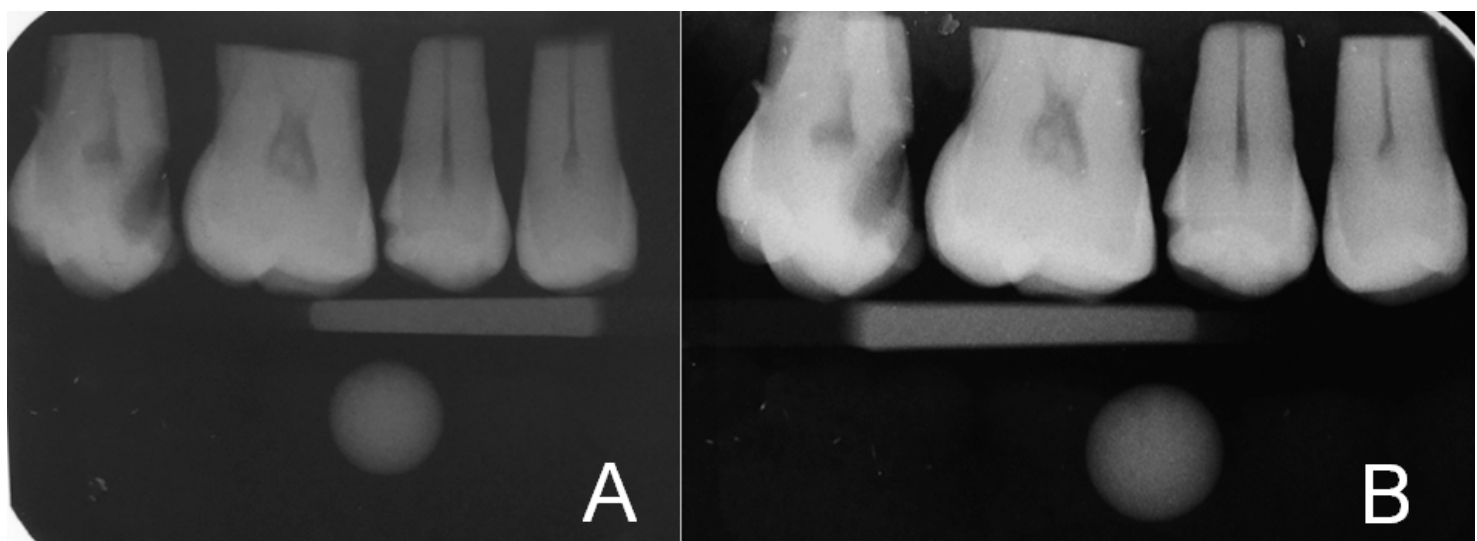

Figure 1. Intraoral bitewing radiographs obtained by (A) Conventional bitewing (KODAK Insight E/F speed film), (B) Phosphor plate bitewing (Instrumentarium Express)

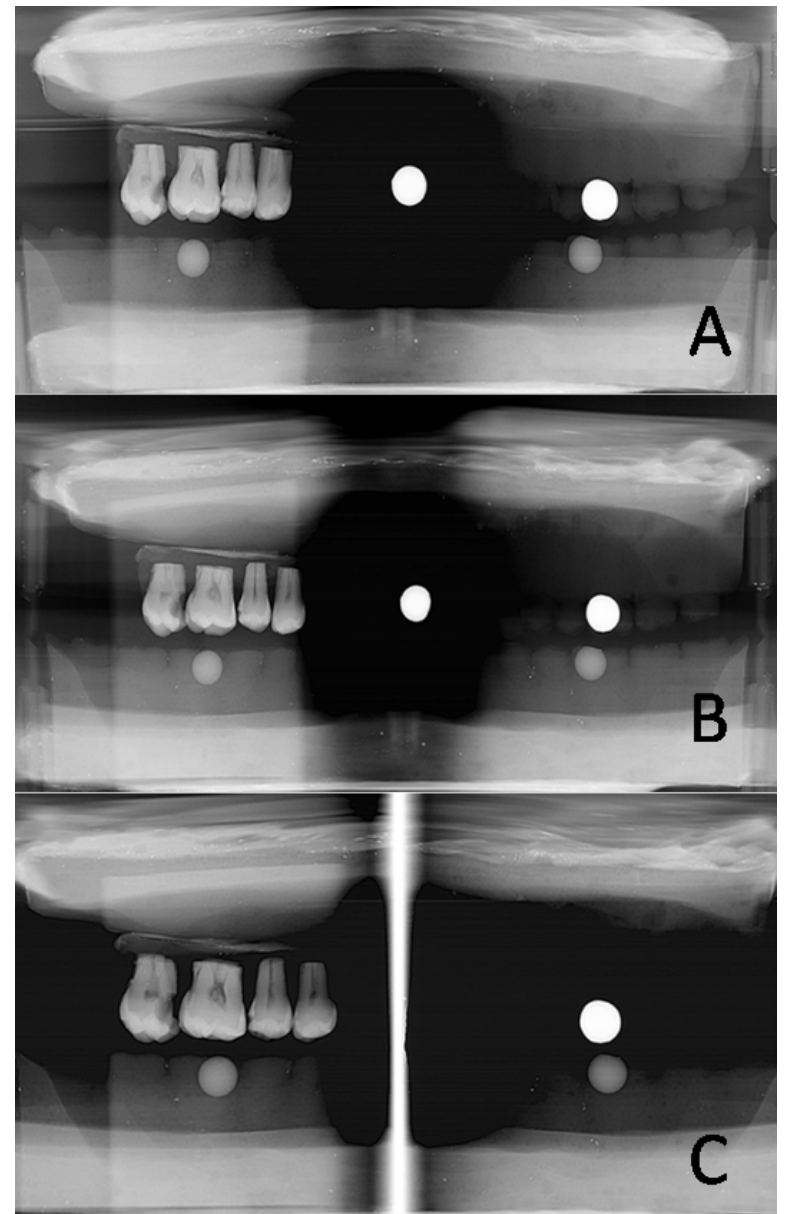

Figure 2. Digital panoramic images obtained by (A) standard program, (B) orthogonal program, (C) bitewing program

\section{Panoramic imaging modalities}

Panoramic radiographs were obtained using Orthopantomograph OP200 (Instrumentarium Dental) with a charge coupled device (CCD) detector at $66 \mathrm{kVp}$ and $4 \mathrm{~mA}$ with $16 \mathrm{sec}$ imaging time for standard (P1) and orthogonal imaging (P4), and $11 \mathrm{sec}$ for extraoral bitewing (BW) imaging. Exposure parameters were determined based on pilot studies to ensure optimal image quality with good visibility of the pulp, enamel and dentin. Each radiograph was obtained with the respective program (standard, orthogonal and extraoral bitewing, respectively, Figure 2).

\section{Evaluation of radiographic techniques}

All images and radiographs were examined in a dimly lit room. Conventional radiographs were examined using a light box and magnifier (x2). All digital images were visualized on a 21.5 inch, thin film transistor (TFT) active-matrix liquid crystal display (iMac, Apple Inc., Cupertino, CA, USA) with a resolution of $1920 \times 1080$ pixels. The use of magnification, density and contrast enhancement tools was unrestricted.

Images were evaluated by two maxillofacial radiologists with 3 and 15 years experience at random order. For intra-observer agreements, images were reassessed at a week interval by each observer.

In order to determine inter-observer agreement for each image, observers first performed their initial assessments individually and then final decision for radiographic scores of each surface was made by consensus of the two observers. Observers scored the absence/presence of proximal caries using a 4-point scale as follows: Score $0=$ sound, Score $1=$ proximal caries in the enamel, Score 2=proximal caries extending to the enamel-dentine junction (EDJ) or in the outer half of dentine, Score 3=proximal caries in the inner half of dentine. ${ }^{16}$ Besides, they were unaware of the caries presence and level in the teeth.

\section{Histological assessment}

To determine the presence or absence of caries, the teeth were individually embedded in acrylic blocks and serially sectioned mesiodistally using an Isomet lowspeed saw (Buehler, Lake Bluff, IL, USA) with a $300 \mu \mathrm{m}$ diamond saw blade. Both sides of each section were examined under a stereomicroscope (x10) (Stemi DV4, Carl Zeiss, Göttingen, Germany) by the two authors who recorded each tooth as either sound or as having a caries lesion. For histological validation, the same 


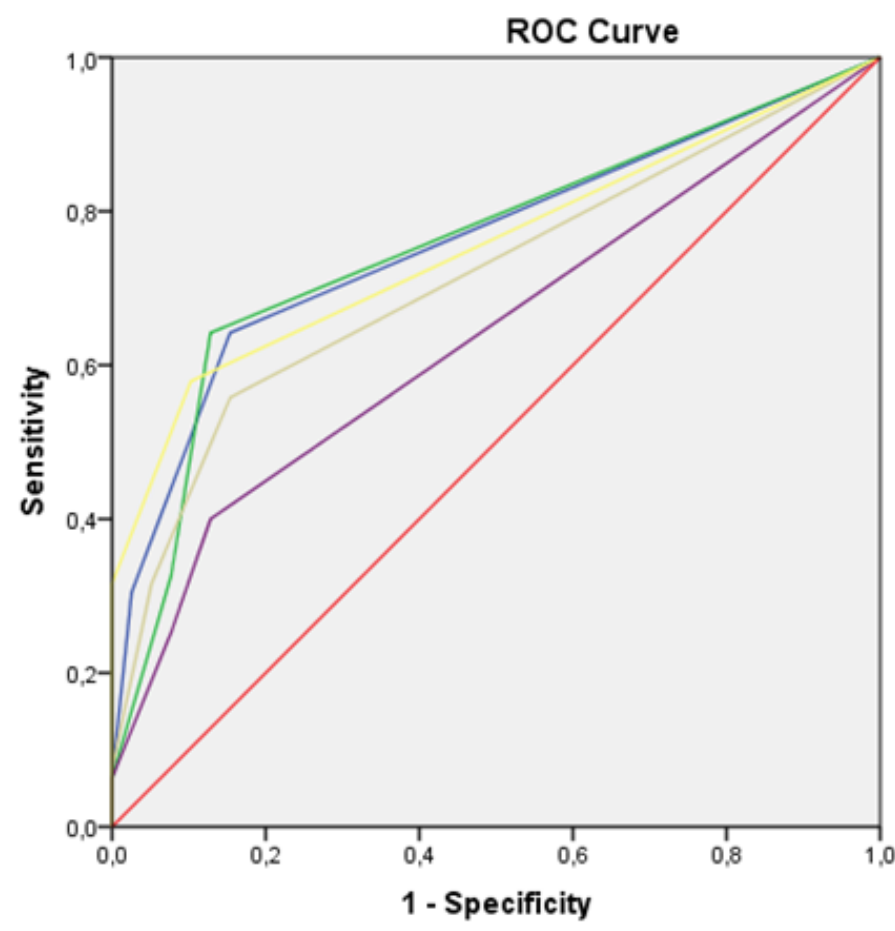

Source of the Curve

- Conventional_bitewing

- Phosphorplate_bitewing

- Orthonal_programme

- Standart_programme

Extraoral_bittewing_

- Reference Line

Diagonal segments are produced by ties.

Figure 3. Receiver operating characteristics (ROC) curve indicating mean sensitivity and specificity values for each imaging method

4-point rating scale used in the radiographic assessment was applied to the approximal surfaces. ${ }^{16}$ The highest score from the various sections of a proximal surface was used to define the caries status of the surface. In cases where the two investigators' ratings diverged, a joint assessment was performed until consensus was reached.

\section{Data analysis}

Weighted-kappa coefficients were calculated to assess the intra- and inter-observer agreement for each image set. Kappa values were evaluated according to the following criteria: <0.10, no agreement; 0.10-0.40, poor agreement; 0.41-0.60, moderate agreement; $0.61-0.80$, strong agreement; and 0.81-1.00, excellent agreement. Weighted-kappa values were calculated using the MedCalc statistical software (MedCalc Software, Mariakerke, Belgium).

Receiver operating characteristics (ROC) analysis was used to evaluate the diagnostic performance of 5 different imaging modalities for detecting caries. Radiographic scores of each image were compared with the histological gold standard. The observers' scores were converted into a ROC curve and Az values were calculated with SPSS v. 20 for Windows (SPSS, Chicago, IL, USA). Z-test was used to analyze the Az values for differences among imaging systems. Z-test was performed using the MedCalc software. Sensitivity, specificity, false-positive and false-negative ratios were calculated for each imaging system. In addition, sensitivity and specificity of imaging systems were compared using Mc Nemar's test.

\section{RESULTS}

In total, 134 approximal surfaces were assessed. Ten surfaces were excluded due to loss of tissue during sectioning and fluorosis. The histological examination revealed that of the 134 proximal surfaces, $39(29 \%)$ were sound, $35(26 \%)$ had enamel caries, $48(36 \%)$ had dentine caries confined to the outer half of the dentine (65\% of these at the enamel-dentin junction), and 12 (9\%) had deep dentine caries extending to the inner half of the dentine.

Intra- and inter-observer weighted kappa coefficients used for establishing agreement between observers are shown in Table 1. Moderate to excellent agreements were observed between the two observers. While the standard program (0.87) showed highest agreement between observers, conventional bitewing had the lowest (0.54).

ROC analysis was performed to compare radiographic scores delivered by observers and histological results and Az values (area under curve) were calculated for each method (Figure 3). While conventional bitewing images had the greatest $A z$ value $(0.760)$, standard program had the lowest $A z$ value (0.639; Table 2). Standard panoramic radiographs were significantly inadequate for caries detection versus 
Table 1. Weighted kappa values for intra- and inter-observer agreements

\begin{tabular}{lcccc}
\hline & \multicolumn{2}{c}{ Intra-observer agreement } & \multicolumn{2}{c}{ Inter-observer agreement } \\
\cline { 2 - 5 } & Observer 1 & Observer 2 & $\begin{array}{c}\text { First } \\
\text { reading }\end{array}$ & Second reading \\
\hline Conventional bitewing & 0.59 & 0.88 & 0.70 & 0.54 \\
Phosphor plate bitewing & 0.76 & 0.85 & 0.75 & 0.69 \\
Standard program & 0.72 & 0.80 & 0.87 & 0.72 \\
Orthogonal program & 0.71 & 0.78 & 0.74 & 0.68 \\
Extraoral bitewing program & 0.70 & 0.70 & 0.69 & 0.68 \\
\hline
\end{tabular}

Table 2. Mean Az values for each image modality

\begin{tabular}{llllr}
\hline & AUC & SE & $95 \%$ CI & $\begin{array}{c}\text { Asymptotic } \\
\text { significance }\end{array}$ \\
\hline Conventional bitewing & 0.760 & 0.042 & $0.678-0.842$ & 0.000 \\
Phosphor plate bitewing & 0.756 & 0.044 & $0.669-0.842$ & 0.000 \\
Standard program & 0.639 & 0.049 & $0.543-0.736$ & 0.012 \\
Orthogonal program & 0.714 & 0.045 & $0.625-0.802$ & 0.000 \\
Extraoral bitewing program & 0.754 & 0.041 & $0.674-0.834$ & 0.000 \\
\hline
\end{tabular}

$A z$ values $(A \cup C)$ : area under the curve, SE: standard error, Cl: confidence interval

other modalities as assessed by dual comparisons of $A z$ values of methods using $z$-test $(p<0.05)$. Comparison of other methods with each other did not show significant differences ( $p>0.05)$.

Sensitivity, specificity, false-negative and falsepositive values for each method are shown in Table 3. Greatest sensitivity was found for images obtained with phosphor plates and conventional bitewing images (0.64) and standard panoramic radiography had the lowest sensitivity (0.40). When the methods were compared pairwise using Mc Nemar's test, conventional and phosphor plate bitewing sensitivities were found to be significantly greater than those of the other modalities $(p<0.05)$. However, all modalities had similar mean specificity values $(p>0.05)$.

Table 4 shows sensitivity and specificity values of each method by the level of caries. While the greatest sensitivity was obtained with conventional bitewing imaging at the level of enamel (0.51), phosphor plates showed the greatest sensitivity for caries extending to the enamel-dentine junction and in the outer half of the dentine (0.73). For the caries in the inner half of the dentine, extraoral bitewing program achieved the highest sensitivity (1.00). All of the studied modalities had lowest sensitivity for detecting caries at the enamel level, with standard program showing the lowest sensitivity at a significant level $(p<0.05)$. No statistically significant differences were observed among modalities in the sensitivity for caries at the EDJ and the outer half of the dentine $(p>0.05)$. However, standard program had significantly lower and extraoral bitewing program had significantly greater sensitivity for the caries in the inner half of the dentine.

\section{Discussion}

In line with advances in technology, preventive dentistry and minimally invasive treatment approaches are currently used in combination with newer systems for dental practice. In addition to newly developed systems, technology for conventional radiography has also seen major improvements as means to identify caries.

Studies establishing histo-pathological data as gold standard for the detection of caries have yielded more reliable findings ${ }^{17}$ and histological data were used as gold standard in the majority of published studies. ${ }^{18-20}$ In the present study, histological data were considered as the gold standard.

Soft tissues in the oral cavity affect the quantity of radiation received by the teeth. For this reason, materials such as acrylic, water and polyvinyl chloride (PVC) blocks have been used in studies which compared radiographic methods. ${ }^{19,21}$ In this in vitro study, a 12$\mathrm{mm}$ thick acrylic phantom was used to simulate soft tissues. On panoramic radiographs taken in vivo, many anatomical structures, soft tissues and air space can obstruct the view of subjacent hard tissues, and ghost images are frequently encountered due to irradiation of a large area. However, this acrylic phantom may not be sufficient for all ghost images seen in in vivo panoramic radiography. 
Table 3. Sensitivity, specificity, false-negative and false-positive values

\begin{tabular}{llccc}
\hline & Sensitivity & Specificity & False positive & False negative \\
& & & ratio & ratio \\
\hline Conventional bitewing & 0.64 & 0.85 & 0.15 & 0.35 \\
Phosphor plate bitewing & 0.64 & 0.87 & 0.12 & 0.35 \\
Standard program & 0.40 & 0.87 & 0.12 & 0.60 \\
Orthogonal program & 0.56 & 0.85 & 0.15 & 0.44 \\
Extraoral bitewing program & 0.59 & 0.90 & 0.10 & 0.41 \\
\hline
\end{tabular}

Table 4. Sensitivity-specificity values for different caries levels

\begin{tabular}{lccc}
\hline & $\begin{array}{c}\text { Enamel caries } \\
(\mathrm{Sn}-\mathrm{Sp})\end{array}$ & $\begin{array}{c}\text { EDJ and outer half of } \\
\text { dentine }(\mathrm{Sn}-\mathrm{Sp})\end{array}$ & $\begin{array}{c}\text { Inner half of dentine } \\
\text { (Sn-Sp) }\end{array}$ \\
\hline Conventional bitewing & $0.51-0.85$ & $0.67-0.85$ & $0.91-0.85$ \\
Phosphor plate bitewing & $0.41-0.87$ & $0.73-0.87$ & $0.91-0.87$ \\
Standard program & $0.23-0.87$ & $0.42-0.87$ & $0.75-0.87$ \\
Orthogonal program & $0.41-0.85$ & $0.49-0.85$ & $0.91-0.85$ \\
Extraoral bitewing program & $0.49-0.90$ & $0.55-0.90$ & $1.00-0.90$ \\
\hline EDJ: enamel-dentine junction Sn: sensitivity, Sp: Specificity & &
\end{tabular}

In most of the studies comparing a variety of intraoral digital systems with different types of films, these modalities were comparable in detection of approximal caries. Particularly, in studies conducted after mid 90s, similar $^{16,22,23}$ or superior ${ }^{4}$ results were reported with intraoral digital systems versus conventional methods in the diagnosis of smaller enamel caries.

Syriopulos et al. ${ }^{20}$ compared E-speed films versus Digora Optime (Soredex, Tuusula, Finland), DenOptix (Denstply/Gendex, Chicago, IL, USA) phosphor plates and Sidexis (Sirona, Bensheim, Germany) and Visualix (Gendex, Milan, Italy) CCD systems for detection of interproximal caries and reported no difference between E-speed films and Digora (Soredex). Hintze and Wenzel $^{24}$ did not find a significant difference between six digital systems with two conventional films in the diagnosis of approximal caries. Consistent with the aforementioned studies, Az values of conventional bitewing radiographs and phosphor plate bitewing radiographs were not statistically significantly different in the current study. Also, among the modalities tested in the present study, greatest sensitivity was achieved with images obtained by conventional and phosphor plate bitewing radiographs. The lowest sensitivity level was observed with standard panoramic images where superimpositions were most prevalent. Extraoral bitewing and orthogonal programs showed lower levels of superimpositions; we believe that this resulted in a lower rate of false-negative results and higher sensitivity versus standard program.

In studies comparing digital intraoral modalities with conventional films for approximal caries detection, different results were obtained due to methodological differences. Civera et al..$^{25}$ reported better detection of enamel and dentine caries with a digital system when they compared Digora (Soredex), a phosphor plate system, with D-speed films. Moystad et al. ${ }^{26}$ compared the accuracy of approximal caries detection using enhanced and unenhanced storage phosphor images and dental $x$-ray film in vitro and reported that enhancement of storage phosphor images improved detection of enamel and dentine caries in comparison to unenhanced images and E-speed film. Castro et al. ${ }^{27}$ compared the diagnostic accuracy of Ekstaspeed Plus films and a direct digital system (Schick CMOSAPS sensor, Sirona) for the detection of approximal caries and found that both had poor performance in the detection of enamel lesions. Mohtavipour et al. ${ }^{28}$ compared an intraoral digital system (RVG, Trophy Radiologie, Paris, France) with F-speed films in the diagnosis of approximal caries and reported that for both modalities, the $\mathrm{Az}$ values were lower in caries restricted to enamel and enamel-dentin junction. Abesi et al. ${ }^{18}$ compared three intraoral modalities, namely E-speed films, PSP Digora PCT (Soredex) and CCD Dixi3 (Planmeca, Helsinki, Finland) in a study using noncavitated approximal surfaces of extracted posterior teeth and found higher sensitivity for films compared to digital systems for the detection of enamel caries, and similar sensitivity for both modalities for dentine caries. In the current study, similar to Abesi et al. ${ }^{18}$ conventional films had greater sensitivity at the enamel 
level compared to phosphor plates; but phosphor plates had greater sensitivity for score 2 caries. We consider that filtration of digital images used in that study may have contributed to these results. In addition, the use of F-speed films with lower contrast could have been a disadvantage for the conventional method used in this study. We believe that the main reason for this could be the large contact area of the posterior teeth and that caries at this level may be concealed by healthy enamel tissue. ${ }^{29,30}$

Pontual et al. ${ }^{31}$ reported that increased histological depth of enamel caries was not significantly correlated with radiographic measurements. Other studies reported that radiographic caries depth was inferior to histo-pathological caries depth with respect to sensitivity for caries detection..$^{4,24}$ Similarly, low sensitivity values were observed with all modalities for the enamel caries in the current study.

Kamburoglu et al. ${ }^{14}$ compared panoramic images (Planmeca Promax) with extraoral bitewing and conventional bitewing (E/F speed film) images obtained by the same panoramic device for the detection of approximal caries. In that study, extraoral bitewing and panoramic images were not different, whereas intraoral bitewing had the greatest accuracy value. However, in the present study, images taken with intraoral modalities were comparable to standard panoramic images but extraoral bitewing method gave more accurate results. This may be explained by minor differences between devices in projection geometry. A distinctive finding of our study was that while all tested modalities had low sensitivity at the enamel level, greatest sensitivity was observed with extraoral bitewing radiographs which also showed comparable sensitivity with conventional bitewing radiographs.

In general, intraoral modalities were found to be superior for detection of approximal caries in studies comparing standard panoramic radiographs with intraoral methods. Kamburoglu et al. ${ }^{14}$ reported that intraoral bitewing radiography was superior in approximal caries detection in comparison to panoramic images. Akkaya et $a l,,^{10}$ comparing the diagnostic accuracy of panoramic and intraoral radiographic surveys for detecting approximal caries, reported that panoramic survey alone was not sufficient for the diagnosis of approximal caries for the entire dentition and the combination of panoramic plus bitewing and anterior periapical survey showed similar diagnostic accuracy with full mouth series. Akarslan et al. ${ }^{32}$ found that the accuracy of digital panoramic images was lower than conventional bitewing and periapical radiographs for the detection of approximal caries. Our findings support these findings.

In an approximal caries study, Scarfe et al. ${ }^{15}$ compared intraoral bitewing, conventional panoramic and orthogonal images with the 'radiographic consensus' value in vivo and reported that, in overall performance, conventional bitewing radiographs achieved a significantly greater diagnostic performance for approximal caries than panoramic images, and standard and orthogonal programs had similar accuracies. Our results are consistent with their findings.

\section{ConCLusion}

Since phosphor plates had similar sensitivity with films for the detection of approximal caries, they may be considered as an alternative to conventional modalities due to their advantages. Extraoral bitewing program is preferable and promising for assessment of approximal caries when intraoral radiography is not possible. All modalities tested in this study had low sensitivity for the detection of enamel caries.

\section{ACKNOWLEDGEMENTS}

This study was supported by Cumhuriyet University Scientific Research Projects Unit (Code: DiŞ-153).

Conflict of interest disclosure: The authors declare no conflict of interest related to this study.

\section{References}

1. Cawson RA, Odell EW, Porter SR. Cawson's essentials of oral pathology and oral medicine, 7th edn. New York: Churchill Livingstone; 2002.

2. Bottenberg $P$, Jacquet $W$, Stachniss V, Wellnitz J, Schulte AG. Detection of cavitated or non-cavitated approximal enamel caries lesions using CMOS and CCD digital X-ray sensors and conventional $\mathrm{D}$ and F-speed films at different exposure conditions. Am J Dent 2011;24:74-8.

3. Manton DJ. Diagnosis of the early caries lesion. Aust Dent $\mathrm{J}$ 2013;58:35-9.

4. Svanaes DB, Moystad A, Larheim TA. Approximal caries depth assessment with storage phosphor versus film radiography. Evaluation of the caries-specific Oslo enhancement procedure. Caries Res 2000;34:448-53.

5. Bloemendal E, de Vet HC, Bouter LM. The value of bitewing radiographs in epidemiological caries research: a systematic review of the literature. J Dent 2004;32:255-64.

6. Poorterman JH, Aartman IH, Kieft JA, Kalsbeek H. Value of bite-wing radiographs in a clinical epidemiological study and their effect on the DMFS index. Caries Res 2000;34:159-63.

7. Ağlarcı OS, Yılmaz HH. Diş hekimliğinde dijital radyografi. Süleyman Demirel Üniv Diş Hek Fak Derg 2010:45-52.

8. Wenzel A. Bitewing and digital bitewing radiography for detection of caries lesions. J Dent Res 2004;83:C72-5.

9. Dowsett D, Kenny PA, Johnston RE. The Physics of Diagnostic Imaging, 2nd edn. London: CRC Press; 2006.

10. Akkaya N, Kansu O, Kansu H, Cagirankaya LB, Arslan U. Comparing the accuracy of panoramic and intraoral radiography in the diagnosis of proximal caries. Dentomaxillofac Radiol 2006;35:70-4.

11. Pillai KG. Oral \& Maxillofacial Radiology: Basic Principles and Interpretation, 1st edn. Delhi: Jaypee Brothers Medical Publishers; 2015.

12. Noujeim M, Prihoda T, McDavid WD, Ogawa K, Seki K, Okano T, et al. Pre-clinical evaluation of a new dental panoramic radiographic system based on tomosynthesis method. Dentomaxillofac Radiol 2011;40:42-6.

13. Ogawa K, Langlais RP, McDavid WD, Noujeim M, Seki K, Okano $\mathrm{T}$, et al. Development of a new dental panoramic radiographic system based on a tomosynthesis method. Dentomaxillofac Radiol 2010;39:4753. 
14. Kamburoglu K, Kolsuz ME, Murat $S$, Yüksel S, Ozen T. Proximal caries detection accuracy using intraoral bitewing radiography, extraoral bitewing radiography and panoramic radiography. Dentomaxillofac Radiol 2012;41:450-9.

15. Scarfe WC, Langlais RP, Nummikoski P, Dove SB, McDavid WD, Deahl ST, et al. Clinical comparison of two panoramic modalities and posterior bite-wing radiography in the detection of proximal dental caries. Oral Surg Oral Med Oral Pathol 1994;77:195-207.

16. Senel B, Kamburoglu K, Ucok O, Yüksel SP, Ozen T, Avsever $\mathrm{H}$. Diagnostic accuracy of different imaging modalities in detection of proximal caries. Dentomaxillofac Radiol 2010;39:501-11.

17. Silva Neto JM, dos Santos RL, Sampaio MC, Sampaio FC, Passos IA. Radiographic diagnosis of incipient proximal caries: an ex-vivo study. Braz Dent J 2008;19:97-102.

18. Abesi F, Mirshekar A, Moudi E, Seyedmajidi M, Haghanifar S, Haghighat $N$, et al. Diagnostic accuracy of digital and conventional radiography in the detection of non-cavitated approximal dental caries. Iran J Radiol 2012;9:17-21.

19. Hintze $H$, Wenzel A. Diagnostic outcome of methods frequently used for caries validation. A comparison of clinical examination, radiography and histology following hemisectioning and serial tooth sectioning. Caries Res 2003;37:115-24.

20. Syriopoulos K, Sanderink GC, Velders $X L$, van der Stelt PF. Radiographic detection of proximal caries: a comparison of dental films and digital imaging systems. Dentomaxillofac Radiol 200;29:312-8.

21. Kielbassa AM, Paris S, Lussi A, Meyer-Lueckel H. Evaluation of cavitations in proximal caries lesions at various magnification levels in vitro. J Dent 2006;34:817-22.

22. Alkurt MT, Peker I, Bala O, Altunkaynak B. In vitro comparison of four different dental X-ray films and direct digital radiography for proximal caries detection. Oper Dent 2007;32:504-9.

23. Haak R, Wicht MJ, Noack MJ. Conventional, digital and contrastenhanced bitewing radiographs in the decision to restore approximal caries lesions. Caries Res 2001;35:193-9.

24. Hintze $H$, Wenzel A. Influence of the validation method on diagnostic accuracy for caries. A comparison of six digital and two conventional radiographic systems. Dentomaxillofac Radiol 2002;31:44-9.

25. Civera VG, Silla JM, Company JM, Navarro LP. Clinical and radiographic diagnosis of approximal and occlusal dental caries in a low risk population. Med Oral Pathol Oral Cir Bucal 2007;12:E252-7.

26. Møystad A, Svanaes DB, Risnes S, Larheim TA, Gröndahl HG. Detection of approximal caries with a storage phosphor system. A comparison of enhanced digital images with dental X-ray film. Dentomaxillofac Radiol 1996;25:202-6.

27. Castro VM, Katz JO, Hardman PK, Glaros AG, Spencer P. In vitro comparison of conventional film and direct digital imaging in the detection of approximal caries. Dentomaxillofac Radiol 2007;36:13842.

28. Mohtavipour ST, Shahsavari F, Haghighat, ASJ, Mohtavipour SS Malekshoar M. In vitro comparison of conventional film and direct digital radiography in proximal caries detection. J Dent Dentomaxillofac Radiol Pathol Surg 2013;1:1-5.

29. Eli I, Weiss El, Tzohar A, Littner MM, Gelernter I, Kaffe I. Interpretation of bitewing radiographs. Part 1. Evaluation of the presence of approximal lesions. J Dent 1996;24:379-83.

30. Weiss El, Tzohar A, Kaffe I, Littner MM, Gelernter I, Eli I. Interpretation of bitewing radiographs, Part 2. Evaluation of the size of approximal lesions and need for treatment. J Dent 1996;24:385-8.

31. Pontual AA, de Melo DP, de Almeida SM, Boscolo FN, Haiter
Neto F. Comparison of digital systems and conventional dental film for the detection of approximal enamel caries. Dentomaxillofac Radiol 2010;39:431-6.

32. Akarslan ZZ, Akdevelioglu M, Güngör K, Erten H. A comparison of the diagnostic accuracy of bitewing, periapical, unfiltered and filtered digital panoramic images for approximal caries detection in posterior teeth. Dentomaxillofac Radiol 2008;37:458-63.

\section{Arayüz çürüklerinin saptanmasında beş farklı tekniğin diagnostik doğruluğu}

\section{ÖZeT}

AmAÇ: Bu çalışmanın amacı, beş farklı radyografik görüntüleme yönteminin posterior dişlerde arayüz çürük teşhisindeki doğruluk değerlerinin karşılaştırılmasıdır.

GEREÇ VE YöNTEM: Çalışmada çürüklü ve çürüksüz 72 adet posterior diş kullanıldı. Geleneksel bitewing radyograflar intraoral film kullanılarak, dijital bitewing radyograflar ise fosfor plak sistem kullanılarak alındı. Panoramik görüntüler dijital panoramik cihazın bitewing, ortogonal ve standart programları kullanılarak elde edildi. Görüntüler iki gözlemci tarafından değerlendirildi. Gözlemci içi ve gözlemciler arası uyum ağırlıklandırılmış kappa katsayısı hesaplanarak belirlendi. Çürük tespitinde altın standart kabul edilen histopatolojik skorlar ile beş yöntemden elde edilen skorlara ROC analizi uygulandı. Yöntemlere ait Az değerleri z-testi ile karşılaştıııldı ve anlamlılık düzeyi 0.05 olarak kabul edildi. Yöntemlere ait sensitivite, spesifisite ve yanlış pozitif oranları hesaplandı.

BULGULAR: Gözlemci içi ve gözlemciler arası uyuma ait $\kappa$ değerleri sırasıyla $0.59-0.88$ ve $0.54-0.87$ arasında değişti. $\mathrm{ROC}$ analizinde ortalama $\mathrm{Az}$ değerleri en yüksek olarak geleneksel bitewing yönteminde $(0.760)$ ve fosfor plak sisteminde (0.756), en düşük olarak ise panoramik cihazın standart programında $(0.639)$ bulundu. Standart panoramik görüntüler çürük teşhisinde diğer yöntemlerden anlamlı olarak yetersiz bulundu $(p<0.05)$. Yöntemlerin sensitivite ve spesifisite değerleri sırasıyla; geleneksel yöntem için

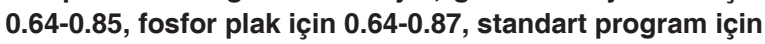
$0.40-0.87$, ortogonal program için $0.56-0.85$, ekstraoral bitewing için $0.59-0.90$ olarak bulundu.

Sonuç: Çalışmada geleneksel bitewing ve fosfor plak bitewing görüntüleri benzer doğruluk düzeyine sahip bulundu. Panoramik cihazdaki ortogonal ve bite-wing programların süperpozisyonların azaltılmasında etkili olduğu gözlendi. Yöntemlerin mine çürüğü düzeyinde sensitiviteleri düşük bulgulandı.

Anahtar KelimeleR: Diş çürükleri; ısırtma radyografisi; panoramik radyografi 